\title{
Annual Dynamics of Winery Wastewater Volumes and Quality and the Impact of Disposal on Poorly Drained Duplex Soils
}

\author{
A.R. Mulidzi ${ }^{*}$, C.E. Clarke $^{2}$, P.A. Myburgh ${ }^{1}$ \\ (1) Soil and Water Science Division, ARC Infruitec-Nietvoorbij, Private Bag X5026, Stellenbosch 7599, South Africa \\ (2) Department of Soil Science, Stellenbosch University, Private Bag X1, Matieland 7602, South Africa
}

Submitted for publication: January 2018

Accepted for publication: June 2018

Keywords: Chemical oxygen demand, electrical conductivity, sodium adsorption ratio, winery wastewater

\begin{abstract}
The composition and volume of winery wastewater change throughout the year. Quality is usually at its worst when vintage operations are dominated by the production of red wines. The objective of this study was to investigate the annual dynamics of winery wastewater volumes and quality, as well as the effect of winery wastewater irrigation on the chemical soil properties of a poorly drained duplex soil. The study was conducted over two and half years. The wastewater contained a high concentration of potassium $\left(\mathrm{K}^{+}\right)$ and low levels of sodium $\left(\mathrm{Na}^{+}\right)$. The results of the study confirmed that winery wastewater did not comply with South African national legislation for wastewater irrigation with regard to chemical oxygen demand (COD) and pH throughout the study period, while some prominent spikes were observed in sodium adsorption ratio (SAR) and electrical conductivity (EC). Land application of winery wastewater resulted in the accumulation of high levels of $\mathrm{K}^{+}$in the soil. It is important to note that this study represents the worst-case scenario, i.e. large amounts of wastewater were disposed of on a small surface, particularly during harvest and in winter. Due to the high volumes of wastewater irrigation plus rainfall, the inevitable over-irrigation leached large amounts of $\mathrm{K}^{+}$beyond $90 \mathrm{~cm}$ soil depth. Unfortunately, the leached elements are bound to end up in natural water resources, resulting in the pollution of the environment.
\end{abstract}

\begin{abstract}
INTRODUCTION
The Western Cape is currently experiencing a drought that will have a negative effect on agricultural production. Although many wineries try to recover some of their wastewater for irrigation, the demand for clean water causes water shortages (Hirzel et al., 2017). Increasing wine production over the last two decades has compelled wine-producing countries to find sustainable winery wastewater management practices that address environmental concerns (Arienzo et al., 2012). Most wineries in South Africa dispose of their wastewater through land application (Van Schoor, 2001). This is carried out by irrigating small areas of cultivated pasture with the wastewater or by ponding, with the former being the more general practice (Mulidzi, 2001). The use of winery wastewater for wine grape production is increasing, and it is therefore important to understand the environmental implication of such a practice (Laurenson et al., 2010). Where wineries use $\mathrm{Na}^{+}$-based cleaning detergents such as sodium hydroxide, the wastewater will contain high levels of $\mathrm{Na}^{+}$(Mulidzi, 2001).

In terms of the South African Department of Water Affairs (2013) general authorisations, most wineries would not
\end{abstract}

qualify to discharge their untreated wastewater into natural water resources. Where the winery wastewater is disposed of through land application, the following requirements, as stipulated in the general authorisations, must be met. It should be noted that, in the current legislation, the volumes that can be applied are not linked to a particular surface area. Up to $500 \mathrm{~m}^{3}$ of wastewater may be irrigated for crop production, including grazing, on any given day, provided that:

- The electrical conductivity (EC) is less than $200 \mathrm{mS} / \mathrm{m}$;

- The $\mathrm{pH}_{(\mathrm{KCl})}$ is between 6 and 9;

- The sodium adsorption ratio (SAR) does not exceed 5; and/or

- The chemical oxygen demand (COD) is less than $400 \mathrm{mg} / \mathrm{L}$. If the COD is higher than $400 \mathrm{mg} / \mathrm{L}$ but less than $5000 \mathrm{mg} / \mathrm{L}$, irrigation (after registration) may not exceed $50 \mathrm{~m}^{3}$ on any given day.

Winery wastewater quality is usually at its poorest when vintage operations are dominated by the production of red wines (Conradie et al., 2014). High pollution loads from July until November are associated with the bottling of

\footnotetext{
*Corresponding author: E-mail address: mulidzir@arc.agric.za

Acknowledgments: The Water Research Commission is thanked for initiating and funding the project. Winetech, THRIP (TP1208066038) and the Agricultural Research Council provided co-funding. We are grateful to the staff of Soil and Water Science at the ARC Infruitec-Nietvoorbij for technical support, and in particular Mr Francois Baron, for his dedicated effort. Any opinions, findings and conclusions or recommendations expressed in any publication generated through THRIP-supported research are those of the authors and therefore the NRF/THRIP will not accept any liability in that regard
} 
white wines, transferring red wines into barrels and filtering the previous year's red wines. In the Southern Hemisphere, harvest is from the end of January until the beginning of April. Winery wastewater produced during harvest will typically contain higher levels of COD and salts than wastewater produced outside the harvest period (Kumar \& Christen, 2009). The disposal of winery wastewater through land application results in the accumulation of $\mathrm{K}^{+}$and $\mathrm{Na}^{+}$in the soil, and sometimes the leaching of $\mathrm{Ca}^{2+}$ and $\mathrm{Mg}^{2+}$, which could lead to instability of the soil structure in the long term (Mosse et al., 2011). Similarly, Lieffering and McLay (1996) also reported that the instability of the soil structure could be associated with the replacement of bivalent ions such as $\mathrm{Ca}^{2+}$ and $\mathrm{Mg}^{2+}$ by monovalent ones such as $\mathrm{K}^{+}$and $\mathrm{Na}^{+}$ during continuous or long-term repeated irrigation. Although the effects of having high $\mathrm{K}^{+}$concentrations in winery wastewater applied to the soil have not been researched extensively, it has been suggested that irrigating with K-rich wastewater could be advantageous to overall soil fertility, but long-term application could result in the alteration of physicochemical soil properties (Mosse et al., 2011).

The current trend to replace sodium hydroxide with $\mathrm{K}^{+}$based cleaning detergents in cellars has the ability to increase the levels of $\mathrm{K}^{+}$in winery wastewater (Arienzo et al., 2012). The accumulation of high levels of $\mathrm{K}^{+}$in the soil is regarded as a potential problem by regulators and the wine industry, because of the negative effects on soil structure and salt accumulation (Mulidzi et al., 2009).

According to Arienzo et al. (2009), the disposal of winery wastewater through land application has the potential to increase the levels of soluble $\mathrm{K}^{+}$and the potassium exchange percentage (EPP) in soils, since most $\mathrm{K}^{+}$in wastewater is immediately available. Soils with a low clay content retained less $\mathrm{K}^{+}$in the exchangeable form, while soils with a higher clay content retained $\mathrm{K}^{+}$to a much greater extent (Smiles $\&$ Smith, 2004). Another study showed that the application of winery wastewater with $\mathrm{K}^{+}$and $\mathrm{Na}^{+}$concentrations of about $400 \mathrm{mg} / \mathrm{L}$ to pastures and woodlots resulted in the accumulation, in the long term, of levels of available $\mathrm{K}^{+}$of $1400 \mathrm{mg} / \mathrm{kg}$ (Kumar \& Kookana, 2006).

The application of winery wastewater that contains high concentrations of bicarbonate cleaning products has the potential to increase soil $\mathrm{pH}$ when applied to land (Laurenson \& Houlbrooke, 2012). An increase in soil $\mathrm{pH}$ due to the application of crop residues is attributed to the addition of cations such as $\mathrm{K}^{+}, \mathrm{Na}^{+}, \mathrm{Ca}^{2+}$ and $\mathrm{Mg}^{2+}$ to plant material (Yan et al., 1996). The disposal of winery wastewater containing high levels of $\mathrm{P}$ can increase the concentration of dissolved $\mathrm{P}$ in runoff. This risk is greatest when rainfall or irrigation occurs immediately after application (Mulidzi et al., 2009). For wineries to use wastewater for the irrigation of their crops it is very crucial to understand the properties of the soil to which the wastewater is applied.

The objective of this study was to investigate the annual dynamics of winery wastewater volumes and quality, as well as the effect of winery wastewater irrigation on the chemical soil properties of a poorly drained duplex soils.

\section{MATERIALS AND METHODS \\ Sites}

The experiment was carried out over two and half years at a winery near Stellenbosch in a newly cultivated pasture grazing paddock to which no winery wastewater had been applied before $\left(-33.4958 .6^{\circ}, 18.4759 .9^{\circ}\right)$. The site was in the centre of wide, flat plains.

The irrigation of a grazing paddock was considered representative of winery wastewater disposal through land application, as this is practised by most wineries in South Africa.

\section{Soil characteristics}

The soil at the winery was classified as a Kroonstad soil form, which consists of an orthic A-E-G horizon sequence (Soil Classification Working Group, 1991). According to the World Reference Base, this soil would classify as a gleyic, albic planosol (IUSS Working Group WRB, 2014). Beneath the topsoil was a bleached, light grey, structureless, apedal sandy horizon (E/albic horizon) to a depth of $50 \mathrm{~cm}$. This reflects an $\mathrm{E}$ horizon that is yellow when moist. Below this horizon is a gleyed clay layer ( $\mathrm{G}$ horizon), indicating a zone of prolonged wetness due to poor drainage. Kroonstad soils commonly occur in the Stellenbosch wine-producing region.

\section{Trial layout}

Three $2 \mathrm{~m} \times 3 \mathrm{~m}$ replication plots were demarcated. Rain gauges were installed on each plot at a height of $0.5 \mathrm{~m}$ to measure the amount of wastewater applied. A two litre plastic bottle was attached to each rain gauge at the irrigation site in order to collect the overflow wastewater when the rain gauge was full. Three rain gauges were also installed outside each paddock for measuring rainfall.

\section{Application of winery wastewater to the soils}

The overhead sprinkler was connected to the main wastewater line from which the winery disposes its wastewater by irrigating kikuyu grass. The volume of wastewater applied and rainwater were recorded weekly by means of rain meters. The field measurements started on 2011-03-01, sampling of winery wastewater commenced in April 2011 and the study ended on 2013-11-30.

\section{Wastewater sampling and analysis}

Winery wastewater samples were collected from the rain meters once a week and their chemical composition was analysed. The COD of the water was measured using a portable spectrophotometer (Aqualitic COD-reactor $\AA$, Dortmund) and the appropriate test kits (COD, CSB, 0 to $15000 \mathrm{mg} / \mathrm{L}$ ). The samples were also analysed by a commercial laboratory (Bemlab, Strand) for $\mathrm{pH}, \mathrm{EC}, \mathrm{P}\left(\mathrm{H}_{2} \mathrm{PO}_{4}^{-}\right), \mathrm{K}^{+}, \mathrm{Na}^{+}, \mathrm{Cl}^{-}$, $\mathrm{HCO}_{3}^{-}, \mathrm{SO}_{4}^{2-}$ and $\mathrm{Fe}^{2+}$ according to the methods described by Clesceri et al. (1998). The $\mathrm{Ca}^{2+}, \mathrm{Mg}^{2+}, \mathrm{K}^{+}$and $\mathrm{Na}^{+}$in the water were determined by inductively coupled plasma optical emission spectrometry (ICP-OES) using a spectrometer (Perkin-Elmer Optima 7300 DV, Waltham, Massachusetts). The cation concentrations in $\mathrm{mg} / \mathrm{L}$ were converted to meq/L in order to calculate the sodium adsorption ratio (SAR), as follows:

$\mathrm{SAR}=\mathrm{Na}^{+} \div\left[\left(\mathrm{Ca}^{2+}+\mathrm{Mg}^{2+}\right) \div 2\right]^{0.5}$ 


\section{Soil sampling and analysis}

Soil was sampled before wastewater monitoring began in March 2011. Thereafter, samples were collected in May, before the winter rainfall, and in November, after the winter rainfall, in 2011, 2012 and 2013. Soils were sampled at 0 to $10 \mathrm{~cm}, 10$ to $20 \mathrm{~cm}, 20$ to $30 \mathrm{~cm}, 30$ to $60 \mathrm{~cm}$ and 60 to $90 \mathrm{~cm}$ depth increments. Soil analyses were done by a commercial laboratory (Bemlab, Strand). Total organic carbon (C) content was determined using the method described by Walkley and Black (1934). The $\mathrm{pH}_{(\mathrm{KCl})}$ was determined in a $1 \mathrm{M}$ potassium chloride $(\mathrm{KCl})$ suspension. Electrical conductivity of the saturated extract (EC ) was determined in a US Bureau of Standards cup. The $\mathrm{Ca}^{2+}$, $\mathrm{Mg}^{2+}, \mathrm{K}^{+}$and $\mathrm{Na}^{+}$were extracted with $1 \mathrm{M}$ ammonium acetate at $\mathrm{pH}$ 7. The cation concentrations from the extracts were obtained by means of atomic emission using an optical emission spectrometer (Varian ICP-OES) at a commercial laboratory (BEMLAB, Strand). For this article, the cations will be referred as extractable calcium $\left(\mathrm{Ca}^{2+}{ }_{\text {extr }}\right)$, magnesium $\left(\mathrm{Mg}^{2+}{ }_{\text {extr }}\right)$, potassium $\left(\mathrm{K}^{+}{ }_{\text {extr }}\right)$ and sodium $\left(\mathrm{Na}^{+}{ }_{\text {extr }}\right)$. The extractable potassium percentage $\left(\mathrm{EPP}^{\prime}\right)$ was calculated as follows:

$$
\mathrm{EPP}^{\prime}=\left(\mathrm{K}^{+}{ }_{\text {extr }} \div \mathrm{S}\right) \times 100
$$

where $\mathrm{K}_{\text {extr }}^{+}$is the extractable potassium $\left(\mathrm{cmol}^{(+)} / \mathrm{kg}\right)$ and $\mathrm{S}$ is the sum of basic cations $\left(\mathrm{cmol}^{(+)} / \mathrm{kg}\right)$. The extractable sodium percentage $\left(\mathrm{ESP}^{\prime}\right)$ was calculated in the same way in order to obtain an indication of the sodicity status. Phosphorus was determined according to the Bray No. 2 method, i.e. extraction with $0.03 \mathrm{M} \mathrm{NH}_{4} \mathrm{~F}$ (ammonium fluoride) in $0.01 \mathrm{M} \mathrm{HCl}$ (hydrochloric acid). The $\mathrm{P}$ concentration in the extract was determined by means of atomic emission, as mentioned above. The soil CEC was also determined, using $0.2 \mathrm{M}$ ammonium acetate $(\mathrm{pH}=7$, as extractant of exchangeable cations) according to the method described by The Nonaffiliated Soil Analyses Work Committee (1990).

\section{Statistical procedures}

The experimental layout was a randomised complete block design with seven sampling times that were randomly replicated within each of the three blocks. During each of the seven time intervals, sampling was done at the aforementioned five depth increments. Univariate analysis of variance was performed for each depth separately on all variables accessed, using the GLM (General Linear Models) Procedure of SAS statistical software (Version 9.2; SAS Institute Inc., Cary, NC, USA). Values for different depths were also combined in a split-plot analysis of variance, with depth as sub-plot factor (Snedecor, 1980). The Shapiro-Wilk test was performed to test for normality (Shapiro \& Wilk, 1965). Student's t-least significant difference was calculated at the $5 \%$ level in order to compare treatment means (Ott, 1998). A probability level of 5\% was considered significant for all the significance tests.

\section{RESULTS AND DISCUSSION \\ Chemical composition of winery wastewater \\ Basic cations}

The wastewater contained high amounts of $\mathrm{K}^{+}$, but relatively low amounts of $\mathrm{Na}^{+}$(Fig. 1A). This indicates that the winery probably used more $\mathrm{K}^{+}$-containing detergents than $\mathrm{Na}^{+}$-based ones. Most of the time, the $\mathrm{Na}^{+}$was less than $70 \mathrm{mg} / \mathrm{L}$, i.e. the
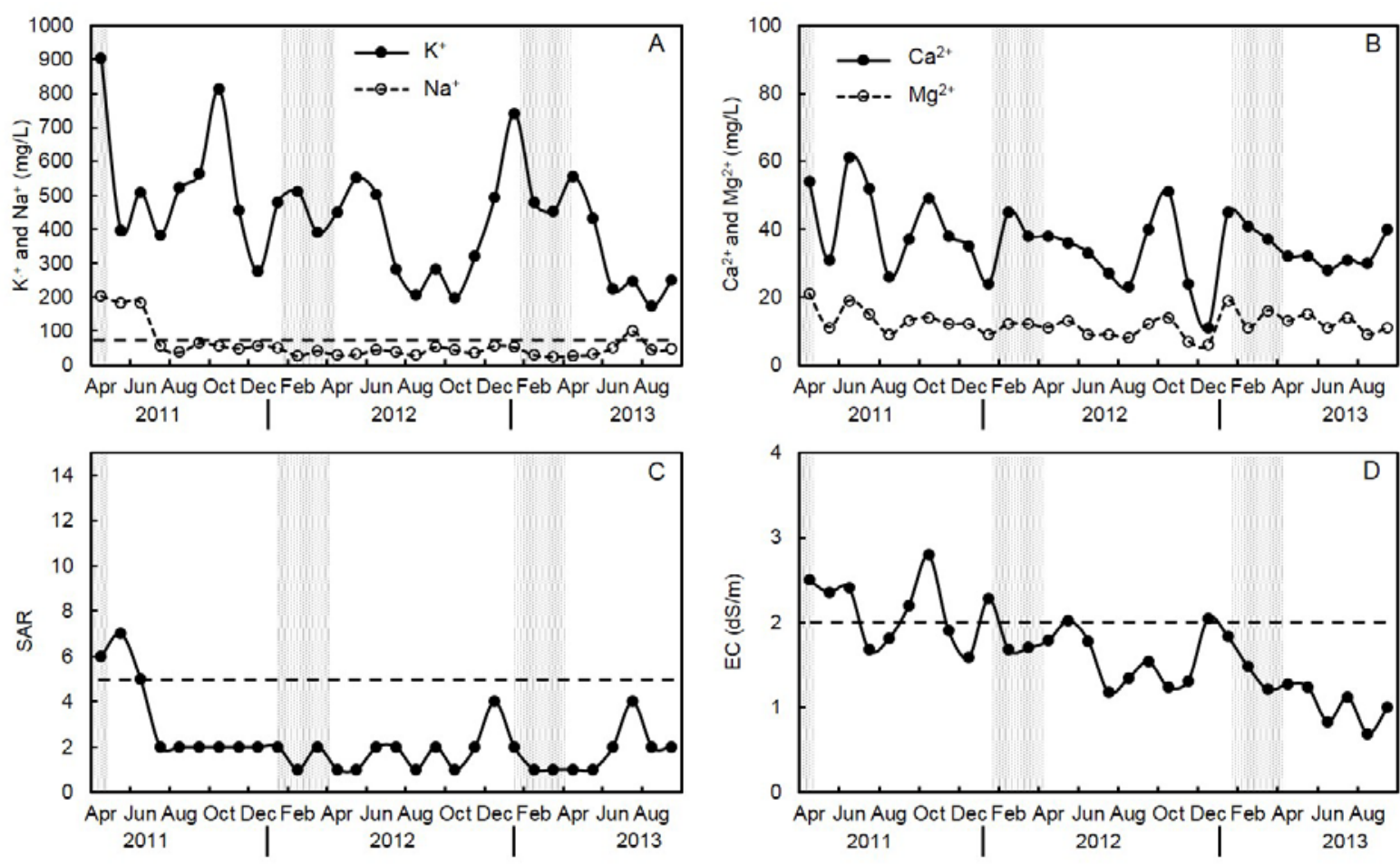

FIGURE 1

Temporal variation in (A) $\mathrm{K}^{+}$and $\mathrm{Na}^{+}$, (B) $\mathrm{Ca}^{2+}$ and $\mathrm{Mg}^{2+}$, (C) sodium adsorption ratio (SAR) and (D) electrical conductivity (EC) of wastewater from a winery near Stellenbosch. Shaded columns indicate the harvest periods. Dashed lines indicate the $\mathrm{Na}^{+}, \mathrm{SAR}$ and EC thresholds. 
upper threshold for unrestricted use with sprinkler irrigation (Ayers \& Westcott, 1994). The annual fluctuation in $\mathrm{K}^{+}$and $\mathrm{Na}^{+}$could not be related to specific seasonal activities in the winery, e.g. grape crushing or bottling. The levels of $\mathrm{Ca}^{2+}$ and $\mathrm{Mg}^{2+}$ in the wastewater were lower than $\mathrm{K}^{+}$and $\mathrm{Na}^{+}$ (Fig. 1B).

\section{Sodium adsorption ratio}

Except in April and May 2011, the wastewater SAR was well below 5, i.e. the legal limit as stipulated in the Department of Water Affairs (2013) general authorisations (Fig. 1C). This indicates that sodic soil conditions were unlikely to develop under the prevailing conditions. Similar to $\mathrm{Na}^{+}$, the wastewater SAR did not follow a distinct annual pattern that could be related to specific winery activities.

\section{Electrical conductivity}

Although the EC of the winery wastewater was initially high (Fig. 1D), it gradually declined and, from January 2012 until the end of the study period, it was below or equal to the legal limit of $2 \mathrm{dS} / \mathrm{m}$ stipulated in the general authorisations of the Department of Water Affairs (2013). This indicates that saline soil conditions were unlikely to develop under the prevailing conditions. It should be noted that the EC did not follow a distinct annual pattern that could be related to specific activities in the winery.

\section{Anions}

The level of $\mathrm{HCO}_{3}^{-}$in the wastewater generally tended to decline over the study period (Fig. 2A). However, the
$\mathrm{HCO}_{3}{ }_{3}^{-}$content was relatively low during the harvest periods. Although irrigation with water containing high levels of $\mathrm{HCO}_{3}$ - could affect soils, plants and irrigation equipment, no guidelines are available (Howell \& Myburgh, 2013, and references therein). Given the high levels of $\mathrm{HCO}_{3}$-in the winery wastewater, negative effects could be expected over time if the water is used for irrigation. The level of $\mathrm{SO}_{4}^{2-}$ in the wastewater was substantially lower than that of $\mathrm{HCO}_{3}^{-}$ (Fig. 2A). Except for some spikes following the harvest period in 2013, the variation in $\mathrm{SO}_{4}^{2-}$ could not be related to a specific activity in the winery. Unlike the $\mathrm{HCO}_{3}^{-}$, the $\mathrm{Cl}^{-}$tended to increase during the harvest periods (Fig. 2B). The $\mathrm{Cl}^{-}$levels in the winery wastewater showed two distinct peaks when the permissible maximum norm of $150 \mathrm{mg} / \mathrm{L}$ for continuous irrigation of grapevines (Howell \& Myburgh, 2013, and references therein) was exceeded. One of these peaks occurred in November 2011, whereas the second coincided with the harvest period in 2013 (Fig. 2B).

\section{Phosphorus}

The variation in $\mathrm{P}$ could not be related to a specific activity in the winery (Fig. 2B). Since the levels of $\mathrm{P}$ in the wastewater were generally low throughout the study period, land application of the wastewater would not make a significant contribution to the $\mathrm{P}$ requirements of crops.

\section{pH}

Except during the harvest periods, the wastewater $\mathrm{pH}$ was within the legal requirement for wastewater irrigation as stipulated in the Department of Water Affairs (2013) general
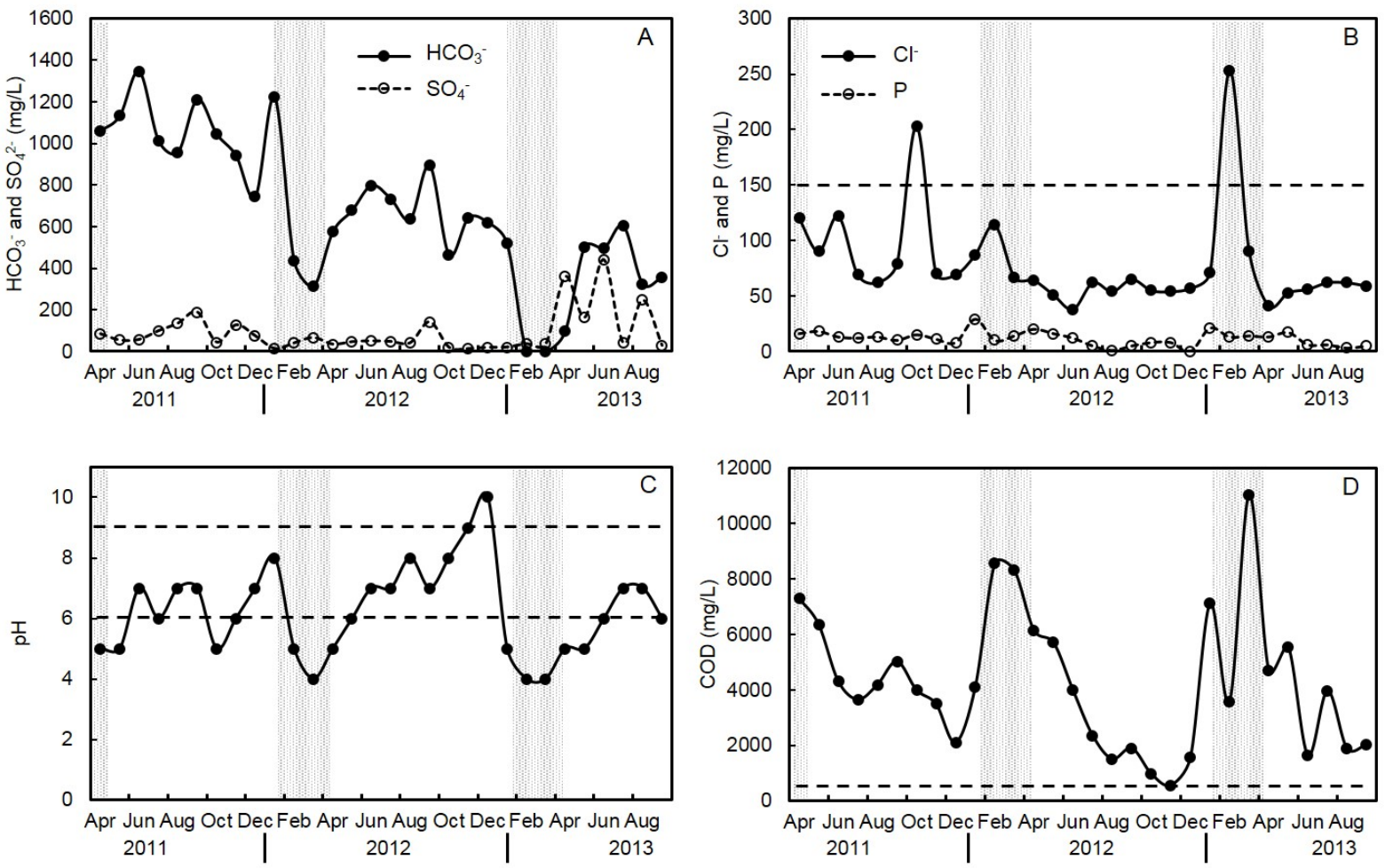

FIGURE 2

Temporal variation in (A) $\mathrm{HCO}^{-}$and $\mathrm{SO}^{2-},(\mathrm{B}) \mathrm{Cl}^{-}$and $\mathrm{P},(\mathrm{C}) \mathrm{pH}$ and (D) chemical oxygen demand (COD) of wastewater from a winery near Stellenbosch. Shaded ${ }^{4}$ columns indicate the harvest periods. Dashed lines indicate the $\mathrm{Cl}^{-}, \mathrm{pH}$ and $\mathrm{COD}^{-}$ thresholds. 
authorisations most of the time (Fig. 2C). Based on the foregoing, the soil was irrigated with suitable water with regard to $\mathrm{pH}$, except during the harvest periods, when the wastewater became acidic.

\section{Chemical oxygen demand}

Annually, the wastewater COD tended to peak during the harvest period (Fig. 2D). This confirms that the crushing and winemaking processes generate wastewater containing high levels of COD. The winery wastewater COD was considerably higher than $400 \mathrm{mg} / \mathrm{L}$ throughout the study period (Fig. 2D). Furthermore, the COD frequently exceeded $5000 \mathrm{mg} / \mathrm{L}$, i.e. the threshold above which wastewater may not be used for irrigation, or for any other land application (Department of Water Affairs, 2013).

\section{Rainfall and volumes of wastewater applied}

Mean monthly rainfall was typical for a Mediterranean climate, i.e. winter rainfall with dry warm summers (Fig. 3). The July rainfall was abnormally low in all the winters. Winter rainfall, i.e. from April to September, amounted to $325 \mathrm{~mm}, 500 \mathrm{~mm}$ and $590 \mathrm{~mm}$ in 2011, 2012 and 2013 respectively. Given that the average rainfall from May to September for Stellenbosch is $465 \mathrm{~mm}$ (Mulidzi, 2016), the winter of 2011 can be considered drier than normal. Winter rainfall in 2012 was similar to the reported average, whereas the rainfall in 2013 was more than normal. As expected, wastewater irrigation amounts increased from January until March (Fig. 4). During the peak of the harvest period, in March, $c a .30 \mathrm{~mm}$ irrigation, or $c a .180 \mathrm{~L}$ per $6 \mathrm{~m}^{2}$ demarcated plot surface area, was applied per day. The irrigation volumes remained relatively high in the winter and began to decline from October to a minimum in December, when the soil received only $c a .1 \mathrm{~mm}$ wastewater per day. Total irrigation applied during the winter, i.e. from April to September, amounted to $2670 \mathrm{~mm}, 4200 \mathrm{~mm}$ and $3820 \mathrm{~mm}$ in 2011,2012 and 2013 respectively. Based on the foregoing, the soil received the highest irrigation plus rainfall in the winter of 2012, followed by 2013 and then 2011 .

\section{Initial soil chemical status and texture}

The soil status at the beginning of the study was acidic, with an average $\mathrm{pH}$ of 4.6 for the profile, which contained $7 \%$ clay (Tables 1 and 2). Soil Bray II P was acceptable throughout the soil profile, although it seemed slightly high for a sandy soil if one considers the norm of $25 \mathrm{mg} / \mathrm{kg}$ proposed by Conradie (1994) for soils containing $6 \%$ to $15 \%$ clay. The $\mathrm{Na}^{+}$extr was relatively low throughout the profile compared to $\mathrm{K}^{+}{ }_{\text {extr }}$ and $\mathrm{Ca}^{2+}$, , which seemed to dominate the exchange capacity (Table 1). The EPP' was relatively high compared to the ESP', which was less than $10 \%$ throughout the profile.

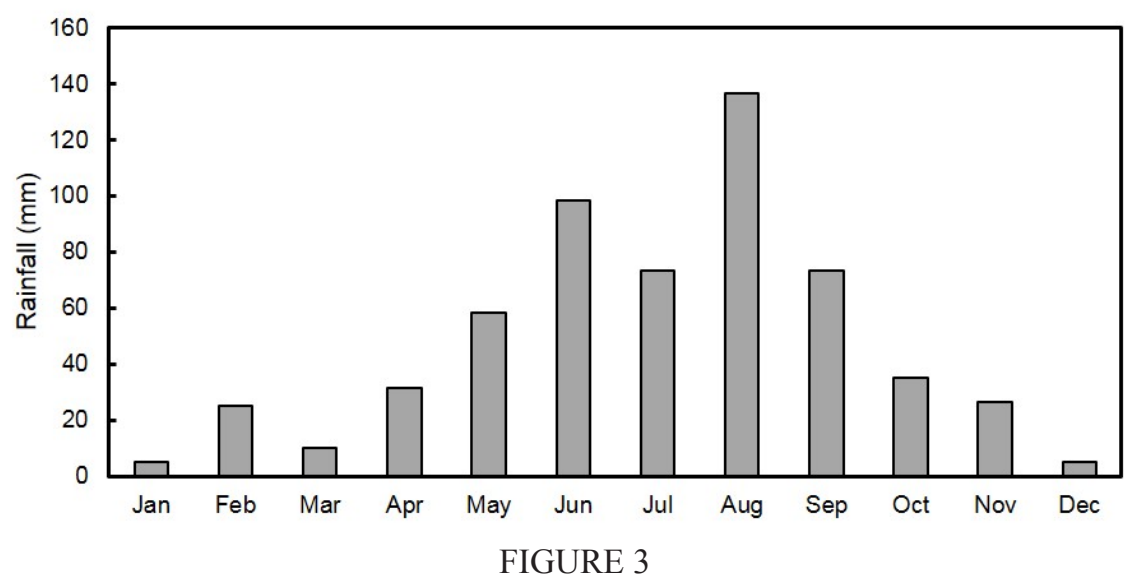

Mean monthly rainfall at a winery near Stellenbosch during the study period.

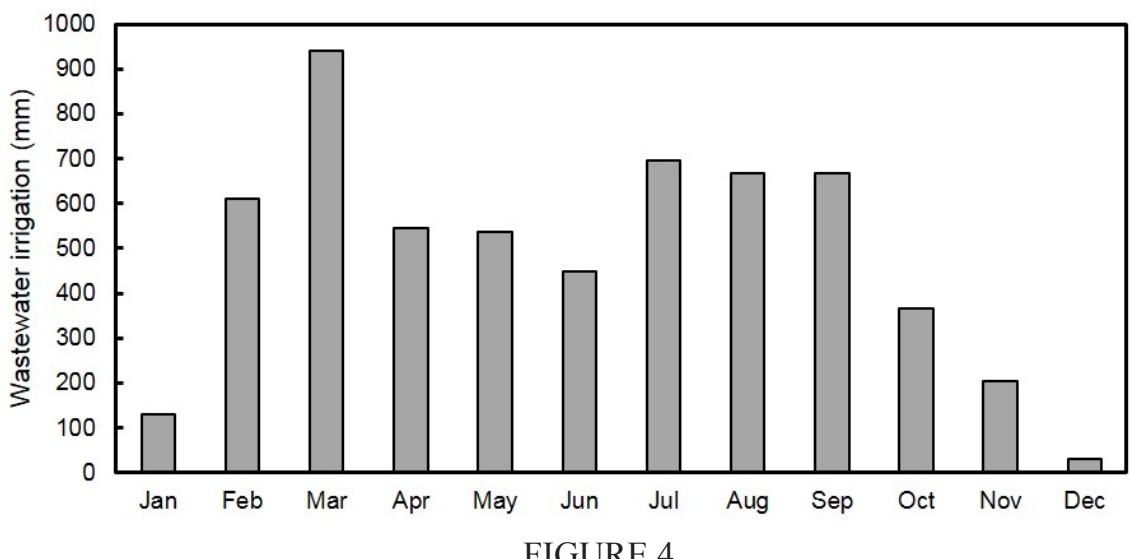

Mean monthly amount of wastewater applied at a winery near Stellenbosch during the study period. 


\section{Soil chemical status during the study period Organic carbon}

The organic $\mathrm{C}$ content in the 0 to $10 \mathrm{~cm}$ layer was significantly higher compared to that in the deeper layers (Fig. 5). During soil classification, visual observation revealed that this layer was rich in organic matter. The initial decline in soil organic $\mathrm{C}$ in the 0 to $10 \mathrm{~cm}$ layer up to November 2011 was somewhat unexpected. Following the initial decline, the organic $\mathrm{C}$ steadily increased up to November 2013. However, the level of organic $\mathrm{C}$ remained below the initial content in March 2011. This indicates that the breakdown of the overburdened organic matter was more rapid than the addition of organic $\mathrm{C}$ through wastewater addition. The organic matter in the 10 to $20 \mathrm{~cm}$ layer showed a similar trend, except that the level at the end of the study period was slightly higher than the initial value (Fig. 5). The organic $\mathrm{C}$ in the deeper layers tended to remain constant over the two-and-a-half-year period. Since the organic $\mathrm{C}$ in the deeper layers remained almost unchanged, it is unlikely that organic $\mathrm{C}$ could have leached from the 0 to $10 \mathrm{~cm}$ soil layer.

\section{Potassium}

Following an initial increase in $\mathrm{K}_{\text {extr }}^{+}$in the 0 to $10 \mathrm{~cm}$ layer of this particular soil that had not previously been irrigated with winery wastewater, $\mathrm{K}^{+}{ }_{\text {extr }}$ remained relatively constant (Fig. 6A). However, a slight increase occurred between November 2011 and May 2012. Although this trend was not significant, the fact that it occurred to a depth

\section{TABLE 1}

The initial chemical status of a duplex soil under a grazing paddock near Stellenbosch before it was irrigated with winery wastewater.

\begin{tabular}{|c|c|c|c|c|c|c|c|c|}
\hline \multirow[b]{2}{*}{ Depth (cm) } & \multirow[b]{2}{*}{$\mathbf{p H}_{(\mathrm{KCl})}$} & \multirow{2}{*}{$\begin{array}{c}\text { Bray II P } \\
(\mathrm{mg} / \mathrm{kg})\end{array}$} & \multicolumn{4}{|c|}{ Basic extractable cations $\left(\mathrm{cmol}^{(+)} / \mathbf{k g}\right)$} & \multirow[b]{2}{*}{$\operatorname{EPP}^{\prime(1)}(\%)$} & \multirow[b]{2}{*}{$\operatorname{ESP}^{\prime(2)}(\%)$} \\
\hline & & & $\mathrm{Na}_{\text {extr }}^{+}$ & $\mathbf{K}_{\text {extr }}^{+}$ & $\mathrm{Ca}^{2+}{ }_{\text {extr }}$ & $\mathrm{Mg}_{\text {extr }}^{2+}$ & & \\
\hline 10 & 4.4 & 50 & 0.17 & 0.6 & 1.1 & 0.3 & 28.1 & 8.2 \\
\hline 20 & 4.6 & 54 & 0.13 & 0.5 & 0.7 & 0.2 & 31.4 & 8.4 \\
\hline 30 & 4.4 & 55 & 0.10 & 0.4 & 0.5 & 0.1 & 35.6 & 9.2 \\
\hline 60 & 4.7 & 42 & 0.10 & 0.4 & 0.6 & 0.1 & 29.8 & 8.1 \\
\hline 90 & 5.0 & 31 & 0.12 & 0.5 & 0.8 & 0.1 & 30.4 & 7.6 \\
\hline
\end{tabular}

(1) Extractable potassium percentage

(2) Extractable sodium percentage

\section{TABLE 2}

Particle size distribution in the 0 to $30 \mathrm{~cm}$ layer of a duplex soil under a grazing paddock near Stellenbosch before it was irrigated with winery wastewater.

\begin{tabular}{ccccc}
\hline \multicolumn{5}{c}{ Particle size (\%) } \\
\hline $\begin{array}{c}\text { Clay } \\
(<\mathbf{0 . 0 0 2} \mathbf{~ m m})\end{array}$ & $\begin{array}{c}\text { Silt } \\
(\mathbf{0 . 0 0 2}-\mathbf{0 . 0 2} \mathbf{~ m m})\end{array}$ & $\begin{array}{c}\text { Fine sand } \\
(\mathbf{0 . 0 2}-\mathbf{0 . 2} \mathbf{~ m m})\end{array}$ & $\begin{array}{c}\text { Medium sand } \\
(\mathbf{0 . 2}-\mathbf{0 . 5} \mathbf{~ m m})\end{array}$ & $\begin{array}{c}\text { Coarse sand } \\
(\mathbf{0 . 5}-\mathbf{~} \mathbf{~ m m})\end{array}$ \\
\hline 7 & 6 & 39 & 26 & 22 \\
\hline
\end{tabular}

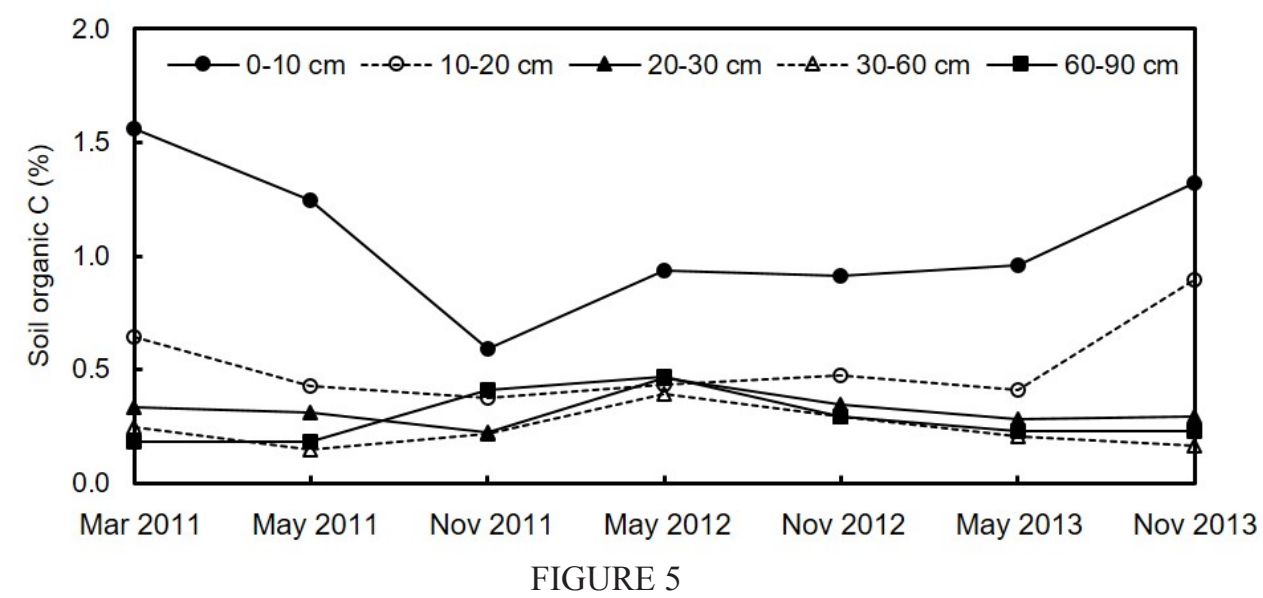

Temporal variation in soil organic $\mathrm{C}$ where winery wastewater was applied to a duplex soil under a grazing paddock near Stellenbosch. 
of $90 \mathrm{~cm}$ suggests that the high irrigation plus rainfall had leached some of the applied $\mathrm{K}^{+}$into the deeper layers. The $\mathrm{K}^{+}$extr in the 60 to $90 \mathrm{~cm}$ layer showed a steady increase over the study period, which indicates that the leached $\mathrm{K}$ was probably steadily accumulating in the deepest layer
(Fig. 6A). Since there was little change in the $\mathrm{K}^{+}$levels with depth throughout the profile, this suggests that most of the applied $\mathrm{K}^{+}$was leached beyond $90 \mathrm{~cm}$. Due to the low clay content of the soil, the exchange complex could not retain large amounts of $\mathrm{K}^{+}$, and the leaching thereof beyond $90 \mathrm{~cm}$
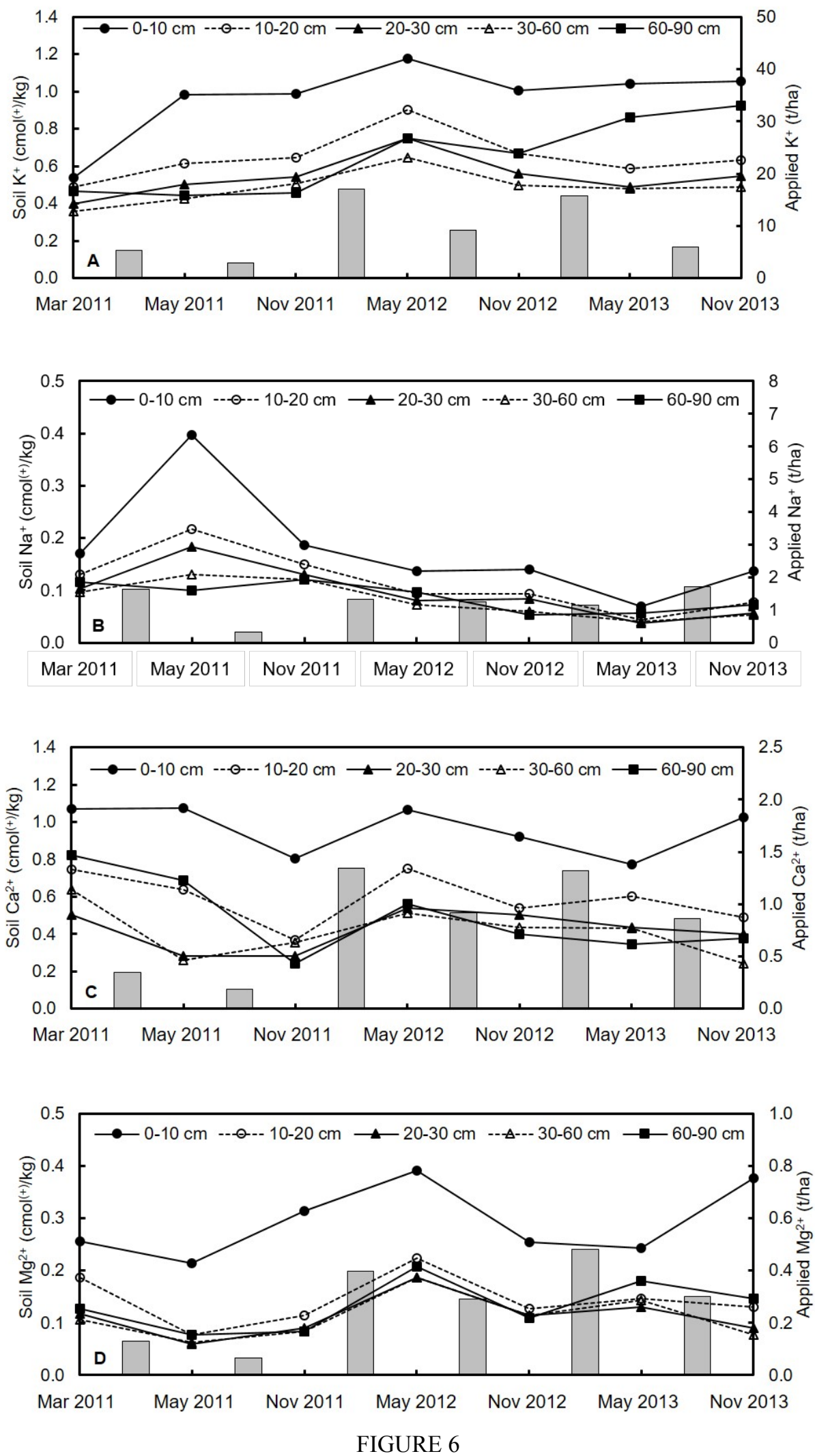

Temporal variation in soil (A) extractable $\mathrm{K}^{+},(\mathrm{B}) \mathrm{Na}^{+},(\mathrm{C}) \mathrm{Ca}^{2+}$ and (D) $\mathrm{Mg}^{2+}$ where wastewater was applied to a duplex soil under a grazing paddock near Stellenbosch. Vertical columns indicate amounts applied of each of the respective cations. 
was not inhibited. Leaching of $\mathrm{K}^{+}$in sandy or coarse-textured soils during winter rainfall reduces the risk of accumulation and dispersion, but increases environmental risks such as contamination of groundwater recharge and/or lateral flow into other fresh water resources.

A previous study showed that the accumulation of $\mathrm{K}^{+}$in soil to which winery wastewater irrigation was applied could be high if it was not absorbed by plants but rather adsorbed to soil particles, thereby reducing the possibility of leaching (Arienzo et al., 2009). Visual observations revealed that the roots of the grass did not extend beyond a depth of $30 \mathrm{~cm}$. This suggests that the large amounts of $\mathrm{K}^{+}$that was applied via the wastewater could not be utilised by the grass, since it had died back.

The negative effect of high levels of $\mathrm{K}^{+}$ions on soil structure is well documented (Levy \& Torrento, 1995, and references therein). However, knowledge on the effect of high levels of $\mathrm{K}^{+}$in soil on soil structure stability due to winery wastewater irrigation is limited (Arienzo et al., 2009).

\section{Sodium}

Except for an initial increase in May 2011, $\mathrm{Na}^{+}{ }_{\text {extr }}$ tended to decline steadily throughout the study period, particularly in the 0 to $10 \mathrm{~cm}$ and 10 to $20 \mathrm{~cm}$ layers (Fig. 6B). The decline was probably due to the small amounts of $\mathrm{Na}^{+}$being applied via the winery wastewater. However, the fact that the specific winery had reduced its use of $\mathrm{Na}^{+}$-based cleaning detergents since 2012 was probably the primary reason for decline in $\mathrm{Na}^{+}{ }_{\text {extr }}$

\section{Calcium}

Although the application of winery wastewater did not increase soil $\mathrm{Ca}^{2+}{ }_{\text {extr }}$ over the study period, this cation displayed limited fluctuations (Fig 6C). It seems that higher applications during the harvest period reflected in the $\mathrm{Ca}^{2+}{ }_{\text {extr? }}$, particularly in 2012. Since the applied $\mathrm{Ca}^{2+}$ was substantially lower than the amounts of $\mathrm{K}^{+}$and $\mathrm{Na}^{+}$, it is unlikely that the $\mathrm{Ca}^{2+}$ would affect the EPP' or ESP' significantly. Therefore, the bivalent cation would probably not counter soil structural problems caused by wastewater containing high levels of $\mathrm{K}^{+}$ and $\mathrm{Na}^{+}$compared to $\mathrm{Ca}^{2+}$. Furthermore, the application of winery wastewater is unlikely to have any benefits of $\mathrm{Ca}^{2+}$ supply to plants, because the wastewater contained only small quantities of this element.

\section{Magnesium}

The $\mathrm{Mg}^{2+}{ }_{\text {extr }}$ in all layers showed only limited fluctuation over the study period (Fig. 6D). However, this was not consistently related to the variations in the amount of applied $\mathrm{Mg}^{2+}$. Similar to $\mathrm{Ca}^{2+}$, the low levels of $\mathrm{Mg}^{2+}$ were unlikely to counter any possible negative effects of high $\mathrm{K}^{+}$and $\mathrm{Na}^{+}$ applications on $\mathrm{EPP}^{\prime}$ or $\mathrm{ESP}^{\prime}$, and consequently on soil physical conditions.

\section{Extractable potassium percentage'}

With the exception of the 0 to $10 \mathrm{~cm}$ layer, the soil EPP' showed a steady increase over the study period (Fig. 7A). The steepest increase occurred in the 60 to $90 \mathrm{~cm}$ layer. Since the $\mathrm{Ca}^{2+}$ and $\mathrm{Mg}^{2+}$ remained relative constant over the study period, the increase in EPP' was probably due to the decline in $\mathrm{Na}^{+}$extr. when this specific winery started to use less $\mathrm{Na}^{+}$-based cleaning agents.

\section{Extractable sodium percentage'}

As expected, the soil ESP' followed the same trend as the $\mathrm{Na}^{+}{ }_{\text {extr }}$ (Fig. 7B). The ESP' showed an increase in May 2011, except in the 60 to $90 \mathrm{~cm}$ layer. This was followed by a steady decline until the end of the study period. Consequently, the ESP' remained below $15 \%$ in all the soil layers, except in May 2011. These results confirm the positive effect of sound winery management practices on the reduction of the potential sodicity hazard if the water is to be used for irrigation of agricultural crops.

\section{Electrical conductivity of the saturated paste extract}

The $\mathrm{EC}_{\mathrm{e}}$ increased with soil depth throughout the study period (Fig. 7C). The salt content in the 0 to $10 \mathrm{~cm}$ layer tended to remain almost constant over the study period, whereas it decreased in the deeper layers up until November 2012. This was followed by an increase in May 2013. However, the $\mathrm{EC}_{\mathrm{e}}$ was lower at the end of the study period compared to the initial values in all layers (Fig. 7C). These results indicate that the salinity hazard was reduced where winery wastewater was applied under the prevailing conditions.

\section{pH}

The soil was acidic, i.e. the $\mathrm{pH}_{(\mathrm{KCl})}$ was below 5.5, in all the layers throughout the study period (Fig. 7D). Furthermore, the $\mathrm{pH}_{(\mathrm{KCl})}$ tended to increase during the harvest period, followed by a decline in winter. This trend was notably less prominent in the 60 to $90 \mathrm{~cm}$ layer. However, the overall effect of irrigation with winery wastewater was that the $\mathrm{pH}_{(\mathrm{KCl})}$ increased in all layers over the study period (Fig. 7D), although the increase was not significant. Application of winery wastewater increased the soil $\mathrm{pH}_{(\mathrm{KCl})}$ from 4.6 to 5.0 in the topsoil and from 5.0 to 5.3 in the subsoil. The $\mathrm{pH}_{(\mathrm{KCl})}$ increase in the topsoil means that organic materials supplied by winery wastewater could be the source of the increase in $\mathrm{pH}_{(\mathrm{KCl})}$. In contrast, leaching of salts into the deeper soil layers could have increased $\mathrm{pH}_{(\mathrm{KCl})}$. According to Rukshana et al. (2012), soil pH increases when organic anions are mineralised and $\mathrm{H}^{+}$ions are consumed following the application of winery wastewater. Although the application of winery wastewater increased the soil $\mathrm{pH}$ by more than 0.2 units, the soil remained acidic under the prevailing conditions.

\section{CONCLUSIONS}

It is important to note that this study represented the worstcase scenario, i.e. large amounts of wastewater were disposed of on a small surface particularly during harvest and winter. With the current drought in the Western Cape province of South Africa, winery wastewater irrigation remains a viable option for agricultural production. The study confirmed that wastewater contains high amounts of $\mathrm{K}^{+}$. The level of $\mathrm{K}^{+}$ and $\mathrm{Na}^{+}$from wastewater reflected the cleaning detergents used at the winery. The study also confirmed that the winery wastewater did not comply with national legislation in terms of COD and $\mathrm{pH}$. Due to the high volumes of wastewater irrigation applied, plus rainfall, the inevitable 

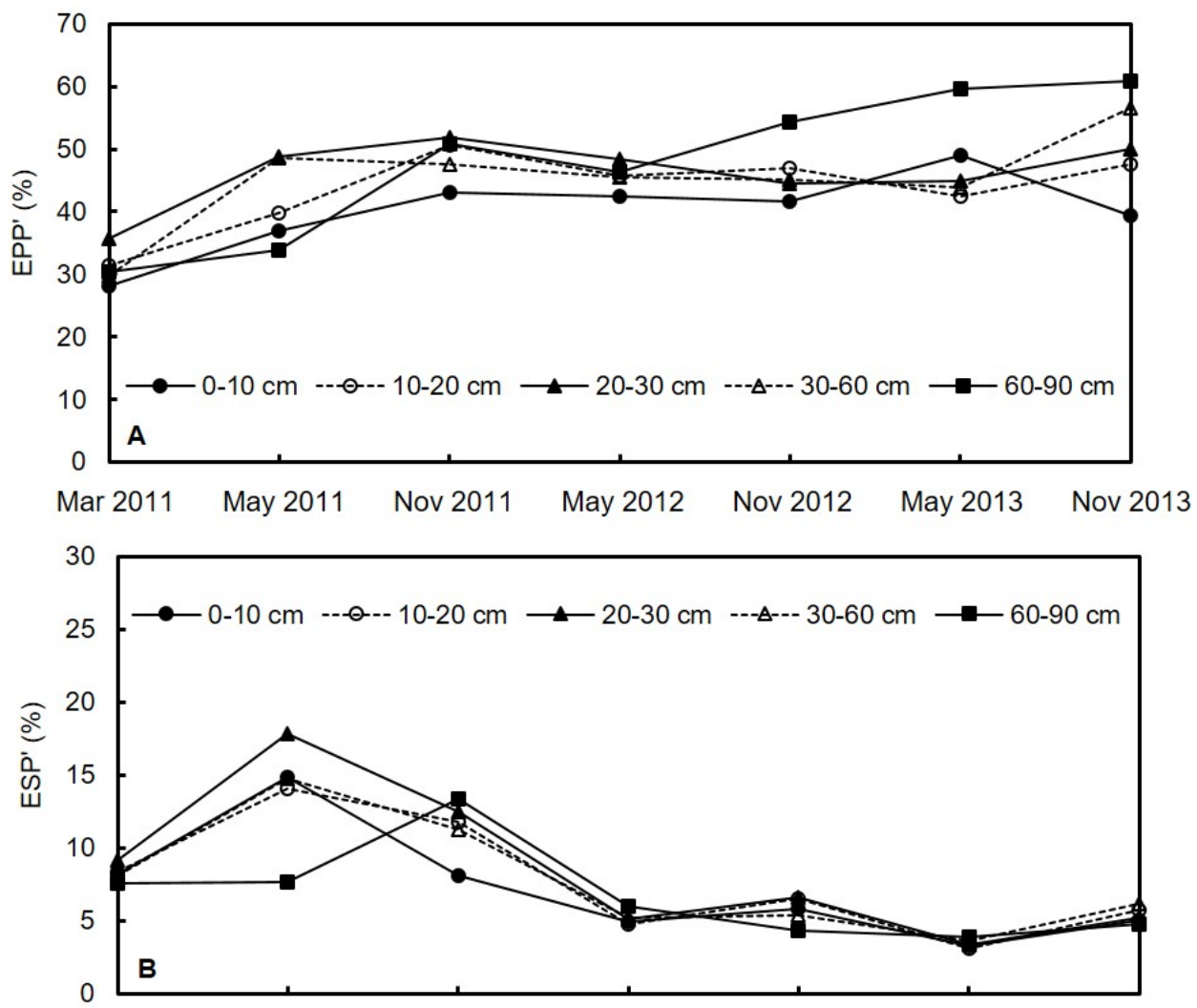

Mar 2011 May $2011 \quad$ Nov 2011 May $2012 \quad$ Nov 2012 May $2013 \quad$ Nov 2013
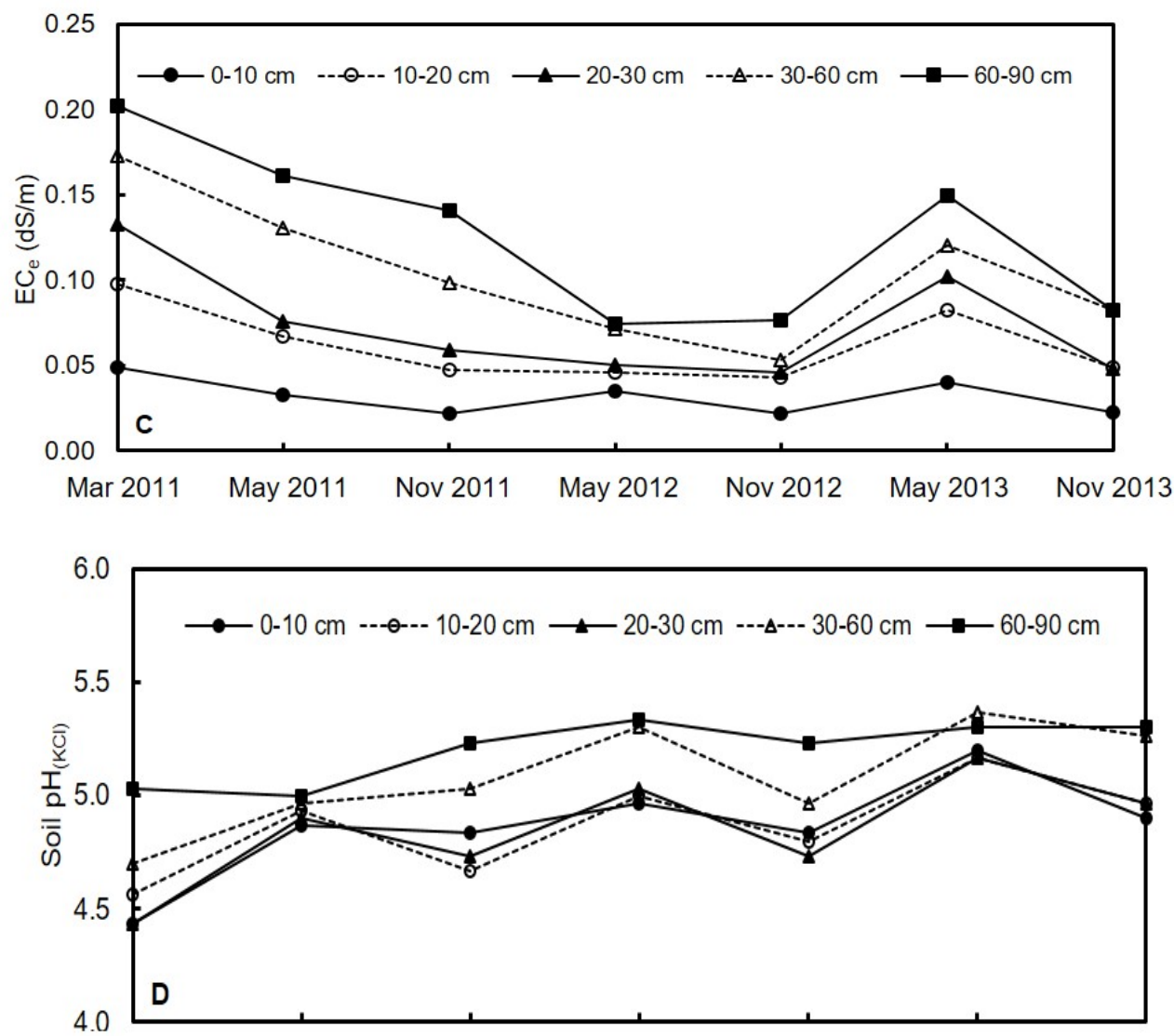

Mar 2011 May 2011 Nov 2011 May 2012 Nov 2012 May 2013 Nov 2013

FIGURE 7

Temporal variation in the $(\mathrm{A})$ extractable potassium percentage $\left(\mathrm{EPP}^{\prime}\right),(\mathrm{B})$ extractable sodium percentage, $(\mathrm{ESP}),(\mathrm{C})$ electrical conductivity of the saturated soil paste extract $\left(\mathrm{EC}_{\mathrm{e}}\right)$ and $(\mathrm{D})$ soil $\mathrm{pH}_{(\mathrm{KCl})}$ where winery wastewater was applied to a duplex soil under a grazing paddock near Stellenbosch. 
over-irrigation leached cations beyond $90 \mathrm{~cm}$ soil depth. The study confirms that irrigation with high volumes of untreated winery wastewater poses a serious environmental hazard, particularly where crops in sandy soils are irrigated. Due to the risks involved, as discussed above, the disposal of winery wastewater by means of irrigation is definitely not the ultimate solution to the problem. Land disposal can only be recommended where the wastewater application does not exceed the water requirement of the grazing crop, or any other agricultural crop. This means that the wastewater needs to be distributed on an area of land that is big enough so that the daily applications do not cause over-irrigation. Wastewater application according to the $\mathrm{K}^{+}$requirement of the crop is also very crucial. The soil chemical status should be determined at least annually.

\section{LITERATURE CITED}

Arienzo, M., Christen, E.W., Jayawardane, N.S. \& Quayle, W.C., 2012. The relative effects of sodium and potassium on soil hydraulic conductivity and implications for winery wastewater management. Geoderma 173-174, 303310 .

Arienzo, M., Christen, E.W., Quayle, W. \& Kumar, A., 2009. A review of the fate of potassium in the soil-plant system after land application of wastewaters. J. Hazard. Mater. 164, 415-422.

Ayers, R.S. \& Westcott, D.W., 1985. Water quality for agriculture. FAO Irrigation and Drainage Paper No. 29. FAO, Rome.

Clesceri, L.S., Greenberg, A.E. \& Eaton, A.D., 1998 (20 th ed). Standard methods for the examination of water and wastewater. American Public Health Association, Washington DC.

Conradie, A., Sigge, G.O. \& Cloete, T.E., 2014. Influence of winemaking practices on the characteristics of winery wastewater and the water usage of wineries. S. Afr. J. Enol. Vitic. 35, 10-18.

Conradie, W.J., 1994. Vineyard fertilisation. Proc. workshop vineyard fertilization, Nietvoorbij, September 1994, ARC Infruitec-Nietvoorbij, Stellenbosch, South Africa.

Department of Water Affairs, 2013. Revision of general authorisations in terms of Section 38 of the National Water Act, 1998 (Act No. 36 of 1998), No. 665. Government Gazette No. 36820, 6 September. Dept. Water Affairs, Pretoria, South Africa. pp. 3 - 31.

Hirzel, D.R., Steenwerth, K., Parikh, S. \& Oberholster, A., 2017. Impact of winery wastewater irrigation on soil, grape and wine composition. Agr. Water Manage. 180, 178-189.

Howell, C.L. \& Myburgh, P.A., 2013. Permissible element concentrations in water used for grapevine irrigation (Part 2) - Anions, trace elements and heavy metals. Wynboer Technical Yearbook 2013, 59-61.

IUSS Working Group WRB, 2014. World Reference Base for Soil Resources. International classification system for naming soils and creating legends for soil maps. World Soil Resources Reports No. 106. FAO, Rome.

Kumar, A. \& Christen, E., 2009. Developing a systematic approach to winery wastewater management. Report CSL05/02 - Final report to Grape and Wine Research and Development Corporation, CSIRO Land and Water Science Report, Adelaide, Australia.

Kumar, A. \& Kookana, R.S., 2006. Impact of winery wastewater on ecosystem health-an introductory assessment. Report CSL 02/03, Grape and Wine Research Development Corporation, CSIRO Land and Water Science, Adelaide, Australia.
Laurenson, S. \& Houlbrooke, D., 2012. Review of guidelines for the management of winery wastewater and grape marc. Report prepared for the Marlborough District Council, New Zealand.

Laurenson, S., Bolan, N., Smith, E. \& McCarthy, M., 2010. Winery wastewater irrigation: Effects of potassium and sodium on soil structure. CRD for Contamination Assessment and Remediation of the Environment, Technical Report no. 19, 1-25.

Levy, G.J. \& Torrento, J.R., 1995. Clay dispersion and macro aggregate stability as affected by exchangeable potassium and sodium. Soil Sci. 160, 352-358.

Lieffering, R.E. \& McLay, C.D.A., 1996. Effects of high pH solutions with large monovalent cation concentrations on cation exchange properties. Aust. J. Soil Res. 34, 229-242.

Mosse, K.P.M., Patti, A.F., Christen, E.W. \& Cavagnaro, T.R., 2011. Review: Winery wastewater quality and treatment options in Australia. Aust. J. Grape Wine Res. 17, 111-122.

Mulidzi, A.R., 2001. Environmental impact of winery effluent in the Western and Northern Cape Provinces. Thesis, University of Pretoria, Private Bag X20, Hatfield 0028, South Africa.

Mulidzi, A.R. 2016. The effect of winery wastewater irrigation on the properties of selected soils from the South African wine region. Dissertation, Stellenbosch University, Private Bag X1, 7602 Matieland (Stellenbosch), South Africa.

Mulidzi, R., Laker, G. Wooldridge, J. \& Van Schoor, L., 2009. Composition of effluents from wineries in the Western and Northern Cape provinces (Part 2): Impacts on soil and the environment. Wynboer Technical Yearbook 2009/10, 62-68.

Ott, R.L., 1998. An introduction to statistical methods and data analysis. Duxbury Press, Belmont, CA.

Rukshana, F., Butterly, C.R., Baldock, J.A., Xu, J.M. \& Tang, C., 2012 Model organic compounds differ in priming effects on alkalinity release in soils through carbon and nitrogen mineralisation. Soil Biol. Biochem. $51,35-43$.

Shapiro, S.S. \& Wilk, M.B., 1965. An analysis of variance test for normality (complete samples). Biometrika 52, 591-611.

Smiles, D.E. \& Smith, C.J., 2004. A survey of the cation content of piggery effluents and some consequences of their use to irrigate soils. Aust. J. Soil Res. 42, 231-246.

Snedecor, G.W. \& Cochran, W.G., 1980 (7 $7^{\text {th }}$ ed.). Statistical methods. The Iowa State University Press, Ames.

Soil Classification Working Group, 1991. Soil classification - A taxonomic system for South Africa. Memoirs on natural resources of South Africa no. 15. Dept. Agric. Developm., Private Bag X116, 0001 Pretoria, South Africa.

The Non-Affiliated Soil Analyses Work Committee, 1990. Handbook of standard soil testing methods for advisory purposes. Soil Sci. Soc. S.A., P.O. Box 30030, Sunnyside, Pretoria.

Van Schoor, L.H., 2001. A formula for the quantification and prioritization of negative environmental impacts in the wine industry. Wineland May, 100-102.

Walkley, A. \& Black, I.A., 1934. An examination of Degtjareff method for determining soil organic matter and a proposed modification of the chromic acid titration method. Soil Sci. 37, 29-37.

Yan, F., Schubert, S. \& Mengel, K., 1996. Soil pH increase due to biological decarboxylation of organic anions. Soil Bio. Biochem. 28, 617-624. 